\title{
Inhibition effect against elastase, collagenase, hyaluronidase and anti-oxidant activity of thinning Green ball apple
}

\author{
Yu-Jin Go ${ }^{1}$ Ye-Eun Kim ${ }^{1} \cdot$ Hyun-Nam Kim ${ }^{1} \cdot$ Eun-Ho Lee $^{1} \cdot$ Eun-Bi Cho $^{1} \cdot$ \\ Akhmadjon Sultanov ${ }^{1} \cdot$ Soon-II Kwon ${ }^{2} \cdot$ Young-Je Cho $^{1}$

\section{그린볼 사과(Green ball apple; Malus pumila Mill.) 적과의 항산화 및 elastase, collagenase, hyaluronidase 저해 효과}

\author{
고유진 ${ }^{1}$ - 김예은 ${ }^{1} \cdot$ 김현남 $^{1}$ - 이은호 ${ }^{1} \cdot$ 조은비 $^{1} \cdot$ Akhmadjon Sultanov $^{1}$ • \\ 권순일 ${ }^{2}$ - 조영제 ${ }^{1}$
}

Received: 22 November 2019 / Accepted: 22 January 2020 / Published Online: 31 March 2020

(C) The Korean Society for Applied Biological Chemistry 2020

\begin{abstract}
In this study, the anti-oxidative, health functional, and beauty food activities of water and ethanol extracts from newly bred Ruby S apple (Malus pumila Mill.). The results of measuring the 1,1-diphenyl-2-picrylhydrazyl radical scavenging activity by treating the phenolic compound with thinning green ball apple at a concentration of $50-200 \mu \mathrm{g} / \mathrm{mL}$ showed that the water and ethanol extracts at a concentration of $200 \mu \mathrm{g} / \mathrm{mL}$ showed 94.69 and $92.24 \%$, respectively. 2,2'-Azinobis-(3-ethylbenzothiazoline6-sulfonic acid) radical scavenging activities showed 100.30 and $99.16 \%$, respectively, in $200 \mu \mathrm{g} / \mathrm{mL}$ of water and ethanol extracts. The water and ethanol extracts of Green ball showed antioxidant protection factor of $1.76 \mathrm{PF} 1.76$, respectively. The water and ethanol extracts showed 101.46 and $99.64 \%$ anti-oxidative effect on thiobarbituric acid reactive substances at phenolic concentration of $200 \mu \mathrm{g} / \mathrm{mL}$. The water and ethanol extracts showed 33.28 and $32.14 \%$ hyaluronidase inhibition, respectively, at phenolic concentration of $150 \mu \mathrm{g} / \mathrm{mL}$. The water and ethanol extracts showed 47.33 and

Young-Je Cho $(\bowtie)$

E-mail:yjcho@knu.ac.kr

${ }^{1}$ School of Food science \& Biotechnology, Kyungpook National University, 80 University Street, Bukgu, Daegu 41566, Republic of Korea

${ }^{2}$ Apple Research Institute, NIHHS, RDA, Gunwi 39000, Republic of Korea

This is an Open Access article distributed under the terms of the Creative Commons Attribution Non-Commercial License (http://creativecommons. org/licenses/by-nc/3.0/) which permits unrestricted non-commercial use, distribution, and reproduction in any medium, provided the original work is properly cited.
\end{abstract}

$40.92 \%$ elastase inhibition and 46.19 and $65.58 \%$ collagenase inhibition at phenolic concentration of $200 \mu \mathrm{g} / \mathrm{mL}$, respectively. About these experiments, thinning Green ball apple was found to exhibit anti-oxidation activity as well as hyaluronidase, elastase and collagenase inhibitory activities. Therefore, thinning Green ball apple can be considered a potential sources for new functional materials.

Keywords Anti-oxidant $\cdot$ Collagenase $\cdot$ Elastase $\cdot$ Hyaluronidase Thinning green ball apple

\section{서 론}

현대 사회에는 항노화에 관한 관심이 상승하는 추세인 가운데 천연물질을 이용한 항산화 원료개발의 의미는 향상되고 있으며 최근에는 아름다움을 중요시 여기고 있는 사회적 관심에 초점 을 맞추어 노화를 늦추거나 미백 효과 또는 주름 개선을 갖는 천연의 항노화 기능성 화장품이 이목을 끌고 있다[1]. 노화는 모든 생물체에서 필연적으로 일어나는 자연현상이며 피부노화 는 내외적인 복합요인에 의해 노화가 일어나는데, 내적인 요인 은 피부노화를 피할 수 없는 자연적인 규율이며 중력, 체내분 비의 기능변화 등을 포함하고 외적인 요인은 주로 환경의 영향 을 많이 받는데 먼지, 자외선, 기후 등의 요인을 포함한다[2]. 이러한 외적인 요인 중에 자외선과 호흡을 통해 형성되는 활성 산소는 피부노화의 가장 중요한 요인이 되며 활성산소는 조직 및 피부세포 손상을 주도한다[3]. 활성이 큰 산소 종에는 
superoxide radical, hydrogen peroxide, hydroxyl radical이 있 다[4]. 이러한 활성산소는 피부 항산화 방어망을 파괴하여 항산 화제와 산화제의 사이에 균형을 산화상태 쪽으로 기울게 하여 산화적 스트레스를 형성하고, 이것은 단백질 산화, 세포간 지질 성분을 파괴하고 DNA산화와 melanin생성반응 촉진과 같은 생 체 구성성분들을 손상시키고 이로 인해 주름생성, 탄력감소 및 주근깨 $\hat{u}$ 기미 발현 등의 피부노화를 가속화한다[3]. 따라서 이러 한 활성산소 감소를 통한 피부노화억제 및 생체방어 등에 대한 연구가 진행되고 있다.

생리활성 효소에는 피부주름을 일으키는 효소로 collagen을 분해하는 효소나 피부탄력을 유지해주는 elastin을 분해하는 효 소 그리고 염증 유발에 관계가 있는 효소 등이 있는데, 이러한 효소들은 천연물질에 함유된 기능성 성분에 의해 억제되어지기 도 하며 이런 성분을 이용해 노화 방지용 식품 및 미용식품을 목적으로 한 다양한 제품군이 개발되고 있다[5].

사과는 장미과로 분류되어지는 작은 낙엽성의 나무로서 아시 아, 유럽 및 북아메리카의 북반구에서 재배되며, 사과에는 당류, 비타민류, 식이섬유 및 phenolic compounds이 다량 함유되어 있다[6]. 또한 사과에는 다양한 종류의 polyphenol 화합물이 존 재하는데 이 물질은 사과의 항산화 활성에 주요한 역할을 하는 천연물질이고[7] 항알러지, 항염증, 주름개선 등의 활성을 나타 내는 것으로 알려져 있으며[6], 동맥경화나 고혈압과 같은 성인 병 예방에 효과가 있다고 알려져 있다[8].

이러한 항산화능과 성인병에 관여하는 성분은 사과에 존재 하는 비타민 $\mathrm{C}$ 라기보다는 파이토케미컬인 퀄세틴, 에피카테킨, 프로시아니딘, B2가 강력한 효능을 보이는 것으로 알려졌다[6]. 과실은 수확의 시기나 성숙에 따라 성분 및 이로 인한 생리활 성에 특이성을 가진다. 블랙 라스베리 과실은 자유라디칼 소거 능 및 환원력 모두 과실이 성숙함에 따라 감소하며, 총 페놀 함 량 및 비타민 함량 역시 과실이 성숙함에 따라 감소하는 것으 로 알려졌으며[5] 딸기의 경우 품종에 따라서 미숙과의 항산화 물질 및 항산화능이 차이가 나는 것을 확인 하였다. 이상의 연 구에서의 결과에 의하면 미숙과의 경우 완숙과에 비해 항산화 효능이 높다는 것을 알 수 있다. 하지만, 사과과실의 재배에서 과육의 품질을 향상시키고 과육크기를 조절할 목적으로 1,2 차 적과를 행하게 되는데, 이때 발생되는 적과의 이용은 극히 제 한적으로 활용되고 있는 실정이다.

따라서 본 연구에서 신품종인 그린볼 사과 재배 시 발생되는 적과의 이용가치를 높이기 위하여 적과가 갖는 다양한 생리활 성을 검토하여서 높은 가치의 기능성 소재로서 개발하고자 시 도하였다.

\section{재료 및 방법}

\section{실험 재료}

본 실험에서 사용된 시험 재료는 경북 군위군 사과연구소에서 교배조합으로 후지(Fuji; 부본)와 골든데리셔스(Golden delicious; 모본)을 이용, 교배한 신육성 품종인 그린볼 사과의 2차 적과를 사용하였다. 시료는 그린볼 사과나무로부터 적과 과정에서 솎아 져 버려지는 적과 열매를 수거하여 열매에서 이물질을 제거 후, 실험 재료로 사용하였다. 그린볼 사과 적과 시료는 작게 토막
낸 후 동결건조(freeze dryer, FD8518, Ilshinbiobase, Yangju, Korea)하여 수분을 제거하고, $40 \mathrm{mesh}$ 로 파쇄하고 $4{ }^{\circ} \mathrm{C}$ 의 저온 고에 보관하여 시료로 이용하였다.

\section{그린볼 사과 적과 추출물 제조}

생리 활성 측정에 사용하기 위한 추출물을 제조할 때 물 추출 물은 그린볼 사과 적과의 분말 $1 \mathrm{~g}$ 을 $200 \mathrm{~mL}$ 증류수(distilled water)에 침지하고 추출물이 $100 \mathrm{~mL}$ 가 되도록 가열한 뒤 상온 으로 냉각하여 24시간 shaking incubator를 이용하여 $4{ }^{\circ} \mathrm{C}$ 에서 교반 추출하였다. Ethanol 추출물의 제조는 $60 \%$ ethanol 100 $\mathrm{mL}$ 에 그린볼 사과 적과 분말 $1 \mathrm{~g}$ 을 넣고 24 시간 동안 교반 추 출을 하였다. 그 후, Whatman No. 1 filter paper (Whatmaninc., Piscataway, New jersey, USA)로 추출물을 여과하고, rotary vacuum evaporator (Eyela NE, Tokyo, Japan)을 사용하여 농 축해서 시료로써 이용하였다.

\section{Total phenolic compound 정량}

Total phenolic coumpound 정량은 Folin와 Denis의 방법[9]에 따라 측정하였고, 시료 $1 \mathrm{~mL}$ 에 증류수 $5 \mathrm{~mL}, 95 \%$ ethanol $1 \mathrm{~mL}$ 와 $1 \mathrm{~N}$ Folin-Ciocalteu reagent $0.5 \mathrm{~mL}$ 를 넣어 vortex하고 5 분 동안 반응시킨 뒤 $\mathrm{Na}_{2} \mathrm{CO}_{3} 1 \mathrm{~mL}$ 를 넣고 1 시간 이내에 725 $\mathrm{nm}$ 의 파장에서 흡광도(Optical density, $\mathrm{OD}$ )를 측정하여 gallic acid 표준곡선을 이용해 양을 환산하였다.

\section{1,1-diphenyl-2-picrylhydrazyl (DPPH) radical 저해 효과}

$\mathrm{DPPH}$ radical 소거능은 Blois이 제시한 방법[10]에 따라 측정하 였다. 그린볼 사과 적과로부터 추출한 phenolic compound를 $50,100,150,200 \mu \mathrm{g} / \mathrm{mL}$ 의 농도로 조절하여 시료를 만들고 이 를 반응구로 하여 각 시료 용액 $1 \mathrm{~mL}$ 와 $60 \mu \mathrm{M} \mathrm{DPPH} 3 \mathrm{~mL}$ 를 혼합하여 vortex하고 실온에서 15 분 동안 방치시킨 후, $517 \mathrm{~nm}$ 에서 $\mathrm{OD}$ 값을 확인하였다. DPPH radical 소거능은 시료 추출물의 반응구와 대조구의 $\mathrm{OD}$ 값 차이로 계산하여 나타내었다.

\section{2,2'-Azinobis-(3-ethylbenzothiazoline-6-sulfonic acid) (ABTS) radical 저해 효과}

ABTS radical 소거능은 Fellegrin 등이 제시한 방법[11]에 따라 측정하였다. 먼저 $140 \mathrm{mM} \mathrm{K} \mathrm{K}_{2} \mathrm{~S}_{2} \mathrm{O}_{8} \quad 88 \mu \mathrm{L}$ 와 $7 \mathrm{mM} \mathrm{ABTS}$ $5 \mathrm{~mL}$ 를 혼합하여 암실에서 약 15 시간 동안 반응시켜서 radical 을 형성하였다. 이것을 ethanol과 약 $1: 88$ 의 비율로 섞고 난 이 후 $734 \mathrm{~nm}$ 에서 대조구 $\mathrm{OD}$ 값이 $0.7 \pm 0.02$ 이 되게 조절한 $\mathrm{ABTS}$ solution을 이용하였다. 반응구에는 $\mathrm{ABTS}$ solution: 그린볼 사과 적과 분말의 phenolic compound를 $50,100,150,200 \mu \mathrm{g} / \mathrm{mL}$ 의 농도로 조절한 시료용액을 $(4 \mathrm{~mL}: 200 \mu \mathrm{L})$ 비율로 혼합하였 고 대조구에는 시료를 대신하여 증류수를 $200 \mu \mathrm{L}$ 첨가하여 vortex하고 1.5 분 동안 반응시킨 후, $734 \mathrm{~nm}$ 에서 $\mathrm{OD}$ 값을 확인 하였다. ABTS radical 소거능 $(\%)$ 은 (1-반응구의 OD값/대조구 의 $\mathrm{OD}$ 값 $) \times 100$ 으로 계산하였다.

\section{Antioxidant protection factor (PF) 측정}

$\mathrm{PF}$ 는 Andarwulan과 Shetty이 제시한 방법[12]에 따라 측정하였 다. 즉, evaporator용 수기에 $50 \mathrm{~mL}$ 의 chloroform에 $30 \mathrm{mg}$ 의 $\beta$-carotene을 녹인 용액 $1 \mathrm{~mL}$ 을 넣고 $40^{\circ} \mathrm{C}$ water bath에서 
chloroform을 완전히 증류시켜 evaporator용 수기 바닥에 있는 침전물에 $184 \mu \mathrm{L}$ tween $40,20 \mu \mathrm{L}$ linoleic acid와 $0.1 \% \mathrm{H}_{2} \mathrm{O}_{2}$ $50 \mathrm{~mL}$ 를 이용해 완전히 녹여 emulsion 용액을 만들고, 그린볼 사과 적과 분말의 phenolic compound를 50, 100, 150, 200 $\mu \mathrm{g} / \mathrm{mL}$ 의 농도로 조절한 시료 $100 \mu \mathrm{L}$ 에 각각 $5 \mathrm{~mL}$ 의 emulsion 을 혼합한 뒤 $50{ }^{\circ} \mathrm{C}$, 암실에서 30 분간 반응시키고 냉각한 다음, $470 \mathrm{~nm}$ 에서 $\mathrm{OD}$ 값을 측정하여 $\mathrm{PF}$ 값은 반응구의 $\mathrm{OD}$ 값 대비 대 조구의 $\mathrm{OD}$ 값으로 나타내었다.

Thiobarbituric acid reaction substance (TBARs) 저해 효과 Buege와 Aust 방법[13]으로 TBARs 값을 측정하였다. $1 \%$ Tween 40 과 $1 \%$ linoleic acid를 동량으로 섞어서 제조한 emulsion 용액의 $0.8 \mathrm{~mL}$ 를 $0.2 \mathrm{~mL}$ 의 시료 용액과 혼합하고 대 조구에는 $0.2 \mathrm{~mL}$ 의 증류수를 시료로 대신하였다. $50^{\circ} \mathrm{C}$ 의 water bath를 이용하여 12 시간 정도 반응시킨 후, $1 \mathrm{~mL}$ 의 반응액에 $4 \mathrm{~mL}$ 의 TBA reagent를 넣고 15 분 동안 끓는 물에 중탕으로 가열하고 10 분 동안 냉각시킨 뒤, 원심 분리를 $2,000 \mathrm{rpm}$ 으로 20 분 동안 한 후 상등액을 $532 \mathrm{~nm}$ 의 파장에서 흡광도를 측정 했다. 그린볼 사과 적과의 저해율 $(\%)$ 은 $100 \times(1$-반응구의 TBARs $\mu \mathrm{M} /$ 대조구의 TBARs $\mu \mathrm{M})$ 의 식을 이용하여 값을 내었다.

\section{Hyaluronidase (HAase) 저해 효과}

HAase의 저해 효과를 측정하기 위해 Dorfman와 Ott의 방법 [14]을 이용하였다. 반응구의 경우에는 그린볼 사과 적과 분말 의 phenolic compound를 $50,100,150,200 \mu \mathrm{g} / \mathrm{mL}$ 의 농도로 조절한 시료 $0.25 \mathrm{~mL}$ 와 $20 \mathrm{mM}$ sodium phosphate phosphate buffer (pH 6.9)에 용해시킨 HAase $(1,000 \mathrm{U} / \mathrm{mL}) 0.25 \mathrm{~mL}$ 를 섞은 후 water bath를 이용해 $38^{\circ} \mathrm{C}$ 에서 5 분 동안 반응시키고 $0.3 \mathrm{M}$ phosphate buffer $(\mathrm{pH} 5.3)$ 에 용해시킨 기질 $(4 \mathrm{mg} / \mathrm{mL})$ 을 $0.25 \mathrm{~mL}$ 넣고 다시 $38^{\circ} \mathrm{C}$ 에서 45 분 동안 반응시키고 난 이후에 $0.04 \mathrm{M}$ acetate buffer (pH 3.7)에 용해시킨 알부민 용액 2.5 $\mathrm{mL}$ 를 첨가하였다. 그 후 5 분동안 방치하고 $600 \mathrm{~nm}$ 에서 투과율 을 측정하였다. 대조구로는 시료를 대신하여 증류수 $0.25 \mathrm{~mL}$ 를 넣고 반응시켰다. 저해율 $(\%)$ 은 (1-시료의 투과율/대조구의 투과 율 $) \times 100$ 의 식을 이용하여 계산하였다.

\section{Elastase 효소저해 효과}

Kraunsoe 등의 방법[15]으로 Elastase 저해활성 효과를 측정하 였다. 그린볼 사과 적과 분말의 phenolic compound를 50,100 , $150,200 \mu \mathrm{g} / \mathrm{mL}$ 의 농도로 조절한 시료 $0.1 \mathrm{~mL}$ 에 $\mathrm{pH} 8.0$ 인 0.2 $\mathrm{M}$ 의 Tris- $\mathrm{HCl}$ buffer $1 \mathrm{~mL}$ 와 $0.8 \mathrm{mM}$ 의 기질액 N-succinyl(Ala)3-p-nitroanilide $0.1 \mathrm{~mL}$, 효소 용액 $1.0 \mathrm{U} / \mathrm{mL}$ porcine pancreatice elastase (Sigma-Aldrich Co., St. Louis, MO, USA) 의 $0.1 \mathrm{~mL}$ 를 혼합하고, 대조구에는 증류수 $0.1 \mathrm{~mL}$ 를 시료로 대 신하여 넣어서 20 분 동안 $37^{\circ} \mathrm{C}$ 에서 반응시키고 5 분 동안 냉각 시킨 뒤 $410 \mathrm{~nm}$ 파장에서 흡광도를 측정하였다. 그린볼 사과 적과의 저해율 $(\%)$ 은 (1-시료 첨가군의 흡광도/대조구의 흡광도) $\times 100$ 의 식을 이용하여 값을 나타내었다.

\section{Collagenase 효소저해 효과}

Collagenase 저해 효과는 Wunsch와 Heidrich가 제시한 방법[16] 에 따라 측정하였으며, $0.1 \mathrm{M}$ Tris- $\mathrm{HCl}$ buffer $(\mathrm{pH}$ 7.5)에
$4 \mathrm{mM} \mathrm{CaCl} 2$ 를 첨가한 후 4-phenylazobenzyloxycarbonyl-ProLeu-Gly-Pro-D-Arg를 $0.3 \mathrm{mg} / \mathrm{mL}$ 의 농도로 녹인 기질 용액 $0.25 \mathrm{~mL}$ 와 그린볼 사과 적과 분말의 phenolic compound를 50 , $100,150,200 \mu \mathrm{g} / \mathrm{mL}$ 의 농도로 조절한 각 시료 용액 $0.1 \mathrm{~mL}$ 을 섞은 뒤, $0.2 \mathrm{mg} / \mathrm{mL}$ collagenase (Sigma-Aldrich Co.) 0.15 $\mathrm{mL}$ 를 첨가하여 실온에서 20 분 동안 반응시킨 뒤 $6 \%$ citric acid $0.5 \mathrm{~mL}$ 를 넣어 반응을 중지시키고 ethyl acetate $2 \mathrm{~mL}$ 를 넣고 vortex하고 $320 \mathrm{~nm}$ 의 파장에서 $\mathrm{OD}$ 값을 확인하였다. Collagenase 저해 효과는 시료용액의 반응구와 대조구의 $\mathrm{OD}$ 값 차이로 계산하여 나타내었다.

\section{통계처리}

모든 실험은 3회 이상 반복 측정하였고 자료의 통계처리는 SPSS 23 for windows (Statistical Package for Social Science, SPSS Inc., Chicago, IL, USA)를 사용하여 평균 \pm 표준편차 (average \pm standard deviation)로 표시한 후 Duncan's multiple range test. one-way ANOVA를 실시하여 시료 추출물 간의 유 의차를 $p<0.05$ 수준으로 하여 비교 분석하였다.

\section{결과 및 고찰}

그린볼 사과 적과로부터 분리한 고형분과 phenolic compound 의 활성 비교

그린볼 사과 적과로부터 분리한 고형분(solid)과 phenolic compound가 생리활성 효과에 어떤 영향을 미치는지 비교하기 위해 $\mathrm{ABTS}$ radical 소거능을 측정한 결과, Fig. $1 \mathrm{~A}$ 와 $\mathrm{B}$ 에서처 럼 그린볼 사과 적과로부터 분리된 phenolic compound는 물 추출물 100 과 $200 \mu \mathrm{g} / \mathrm{mL}$ 의 농도에서 각각 $94.16,99.6 \%$ 의 radical 소거능을 나타내었고, ethanol 추출물 100 과 $200 \mu \mathrm{g} / \mathrm{mL}$ 의 농도에서는 각각 $86.94,100.10 \%$ 의 radical 소거능을 나타내 었다. 반면 그린볼 사과 적과로부터 분리한 water soluble solid 100 과 $200 \mu \mathrm{g} / \mathrm{mL}$ 농도에서 각각 $11.63,16.38 \%$ 의 radical 소거 능을 나타내었고, ethanol soluble solid의 100 과 $200 \mu \mathrm{g} / \mathrm{mL}$ 농 도에서는 $17.86,30.58 \%$ 의 radical 소거능이 나타내었다. 따라서 그린볼 사과 적과로부터 분리된 phenolic compound의 경우에는 물, ethanol 추출물 모두 높은 radical 소거능을 가지고 있지만 그린볼 solid의 경우에는 물, ethanol 추출물 모두 낮은 radical 소거능을 나타낸다는 것을 확인할 수 있었다. 따라서 그린볼 사 과 적과의 생리활성에는 phenolic compound가 관여하는 것으로 확인되어 향후 실험에서는 phenolic compound를 대상을 진행되 었다.

\section{그린볼 사과 적과 추출물의 DPPH radical 저해 효과}

$\mathrm{DPPH}$ radical 소거능은 지질과 산화 반응에서 연쇄반응에 관여 하는 산화성 free radical에 전자를 공급하여 연쇄반응을 중지시 킨다. 산화성 free radical은 지질, 단백질, 등 인체 내 물질과 결합하여 각종 질병 및 노화를 일으키는 척도가 되므로 radical 소거능은 인체의 질병과 노화 방지에 관여한다고 알려져 있다. $\mathrm{DPPH}$ 법은 항산화 물질의 DPPH radical 소거능으로 인해 $\mathrm{DPPH}$ 가 환원되어 보라색에서 노란색으로 색이 탈색되는 정도 를 이용하여 항산화 효과를 측정할 수 있는 척도로 알려져 있 

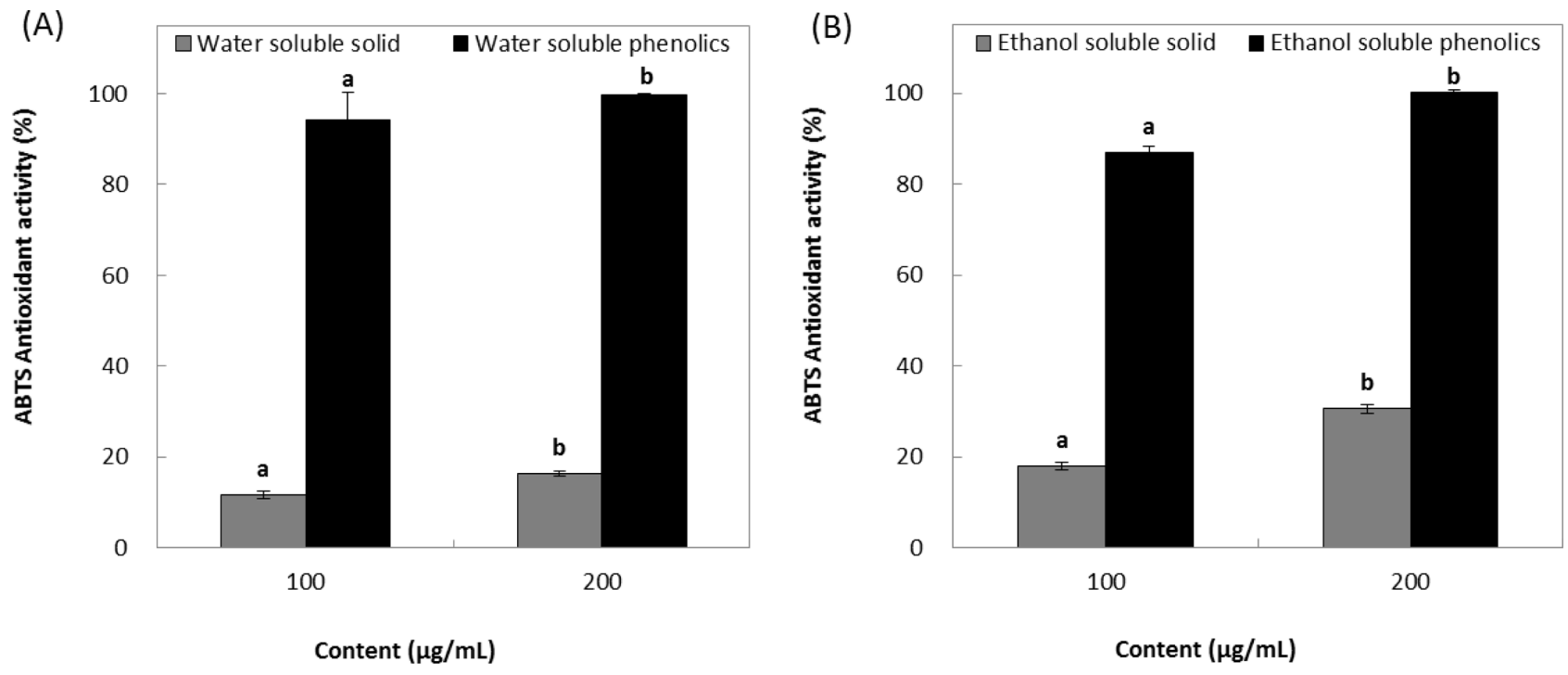

Fig. 1 ABTS activity on solid and phenolic from green ball water extract (A) and ethanol extract (B). Means with different superscript letters (a-b) are significantly different at $p<0.05$ by a Duncan's multiple range tests

다[17]. 그린볼 사과 적과 추출물을 이용하여 DPPH radical 소 거능을 측정한 결과 Fig. $2 \mathrm{~A}$ 와 같이 phenolic compound 50$200 \mu \mathrm{g} / \mathrm{mL}$ 농도의 물과 ethanol 추출물은 각각 $89.16-94.69 \%$ 와 90.75-92.24\%의 DPPH radical 소거능을 나타냈으며, positive control로 사용한 butylated hydroxytoluene (BHT)의 DPPH radical 소거능인 DPPH 67.93-77.11\%보다 높은 DPPH radical 소거능을 나타낸다. Kang 등[18]이 참당귀의 물과 methanol 추 출물이 500 과 $1,000 \mu \mathrm{g} / \mathrm{mL}$ 농도에서 각각 $47.1,66.3,45.6$, $81.5 \%$ 의 DPPH radical 소거능을 나타낸다고 보고한 것과 비교 했을 때 그린볼 사과 적과 추출물의 DPPH radical 소거능이 더 우수하다고 판단되었다.

\section{그린볼 사과 적과 추출물의 ABTS radical 저해 효과}

$\mathrm{ABTS}$ 방법은 ABTS의 양이온 radical의 흡광도는 항산화 물질 에 의해 억제되어서 특유의 청록색으로 색이 변하는 현상을 사 용한 방법으로[19], ABTS radical 소거능은 aqueousphase과 organicphase에 적용 가능한 방법이고 또 hydrogendonating antioxidants와 chaninbreaking antioxidants를 측정할 수 있다 [20]. 그린볼 사과 적과 추출물을 이용하여 ABTS radical 소거 능을 측정한 결과 Fig. 2B와 같이 phenolic compound 50-200 $\mu \mathrm{g} / \mathrm{mL}$ 농도의 물과 ethanol 추출물은 각각 $56.12-100 \%$ 와 $53.15-99.16 \%$ 의 ABTS radical 소거능이 나타내며, positive control로 사용한 페놀계 산화방지제의 일종인 BHT[21]의 ABTS radical 소거능인 28.84-69.62\%보다 높은 ABTS radical 소거능을 나타내었다. Kim과 Kang의 연구결과[22]에 따르면 참 외 줄기 - 잎의 ethanol 추출물 100 과 $200 \mu \mathrm{g} / \mathrm{mL}$ 농도에서 각 각 41.4 와 $55 \%$ 의 $\mathrm{ABTS}$ radical 소거능을 나타냈다고 보고한 것과 비교했을 때 그린볼 사과 적과 추출물의 ABTS radical 소 거능이 더 우수하다고 판단되었다.

\section{그린볼 사과 적과 추출물의 $\mathbf{P F}$ 측정}

$\beta$-Carotene은 지용성 비타민이므로 지질 산화과정 중 생성되는 peroxy radical과 $\beta$-carotene이 반응하여 불활성물이 생성되고, 이 물질이 free radical에 의한 연쇄 반응을 중지시켜 singlet oxygen을 억제한다[23]. PF는 $\beta$-carotene이 산화될 때의 변화를 이용한 항산화 효과 측정법으로, 지방산이 산패될 때 생성된 물 질에 의해 $\beta$-carotene이 산화되어 특유의 색을 감소하는 것을 측정하여 지방산의 초기 산패 여부를 알 수 있다[24]. 그린볼 사과 적과 추출물로 $\mathrm{PF}$ 를 측정한 결과 Fig. $2 \mathrm{C}$ 에서와 같이 phenolic compound $50-200 \mu \mathrm{g} / \mathrm{mL}$ 농도의 물과 ethanol 추출물 은 각각 1.38-1.76 $\mathrm{PF}$ 와 1.23-1.76 $\mathrm{PF}$ 의 값을 나타냈으며, positive control로 사용한 BHT의 1.07-1.29 PF보다 높은 값을 나타내었다. $\operatorname{Lim}$ 등[25]이 야생 곰취잎 물 추출물이 $200 \mu \mathrm{g} / \mathrm{mL}$ 에서 $1.02 \mathrm{PF}$ 를 나타내었다고 보고한 결과와 비교하였을 때, 그 린볼 사과 적과 추출물의 지용성 물질에 대한 항산화 효과가 더 우수하다고 판단되었다.

\section{그린볼 사과 적과 추출물의 TBARs 저해 효과}

지방의 산패도를 나타내는 TBARs 값은 TBA 시약과 반응해서 붉은색을 나타내는 malondialdehyde의 생성량을 측정한 것이다 [26]. $50-200 \mu \mathrm{g} / \mathrm{mL}$ phenolic 농도에서 TBARs를 측정한 결과 는 Fig. $2 \mathrm{D}$ 와 같이 물 추출물에서는 91.80-101.46\%의 활성을, ethanol 추출물에서는 95.08-99.64\%의 활성을 나타냈으며, 대조 구인 BHT는 97.34-100.48\%의 활성을 나타내었다. Kim 등[27] 이 노간주 나무를 $500 \mu \mathrm{g} / \mathrm{mL}$ 농도의 물 추출물과 ethanol 추출 물의 항산화를 측정하였을 때 각 55 와 $71 \%$ 의 항산화 활성 효 과를 나타냈다고 보고하였다. 따라서 그린볼 사과 적과 추출물 이 높은 지용성 항산화능을 가진 것을 확인할 수 있었다.

\section{그린볼 사과 적과 추출물의 HAase 저해 효과}

히아루론산(hyaluronic acid; HA)은 조직내의 간질에 널리 분포 되어있는 고분자 다당이다[28]. HA는 섬유아 세포에서부터 산 출되고, 표피와 진피에 있어서 주요한 세포외기질(extracellular matrix)로서 존재하는 글루쿠론산(glucuronic acid)와 글루코사민 


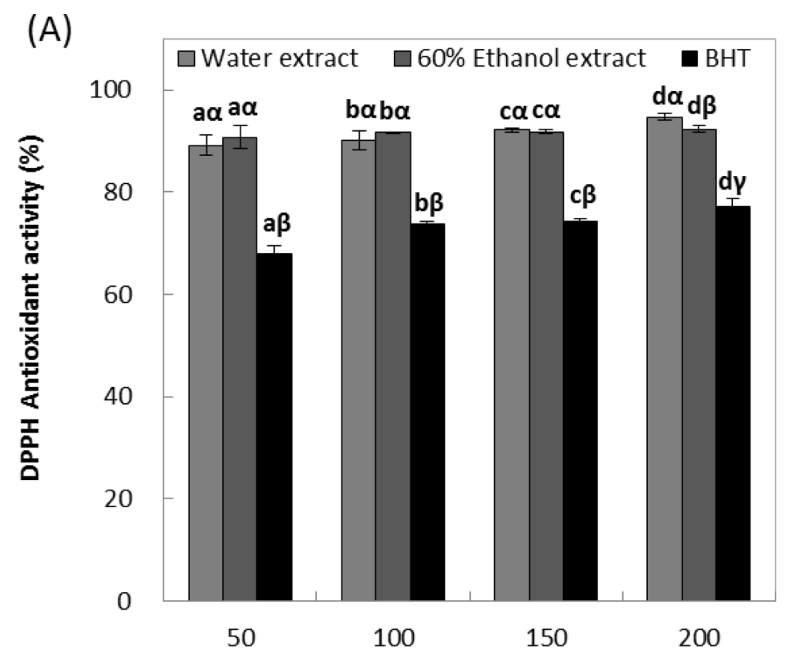

Phenolic content $(\mu \mathrm{g} / \mathrm{mL})$

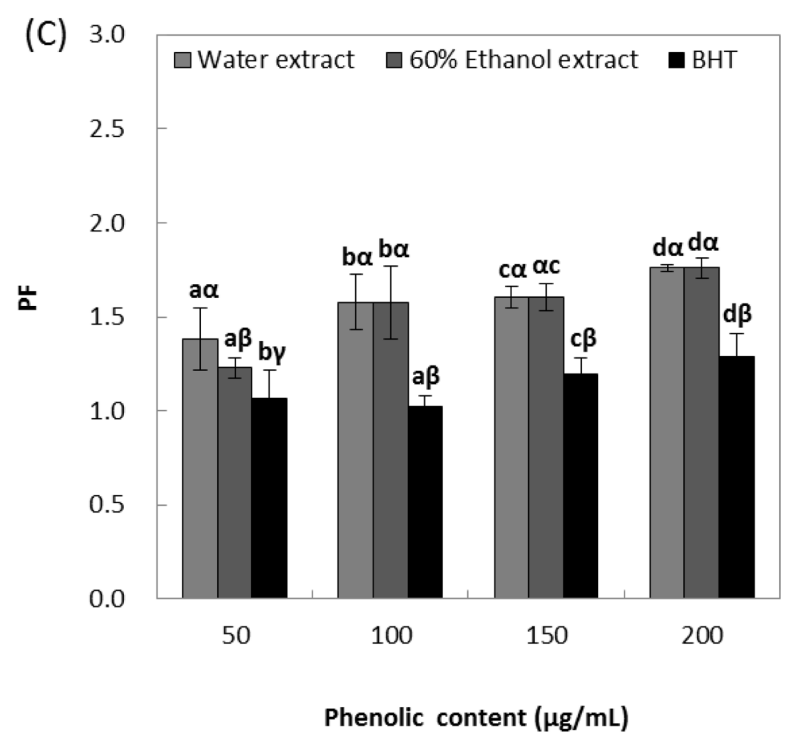

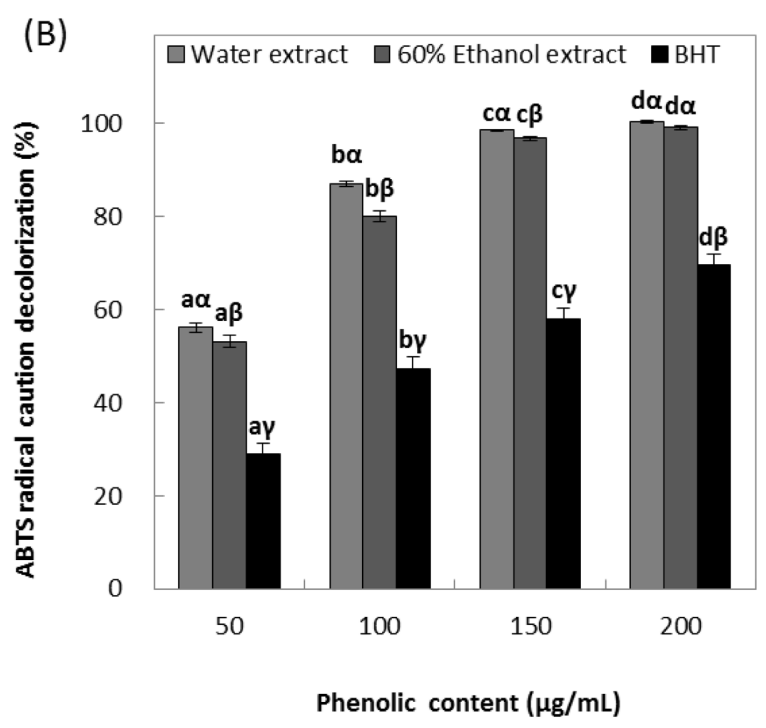

(D)

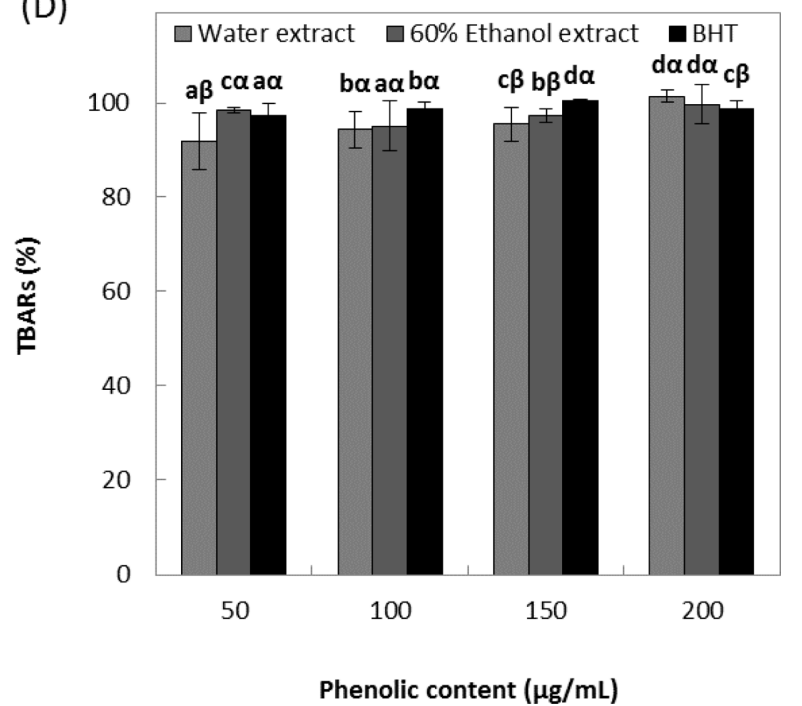

Fig. 2 antioxidant activity of water, 60\% ethanol extracts from Malus pumila Mill. (A): DPPH, (B): ABTS, (C): PF, (D): TBARs. Means with different superscript letters (a-d), $(\alpha-\gamma)$ are significantly different at $p<0.05$ by a Duncan's multiple range tests

(glucosamine)이 반복 연결된 점액성moucopolysaccharide로서 세 포간 분자에서 3 차원적 가교역할을 한다[20,28]. 고분자의 HA 의 경우 염증 형성에서 중요 원인인 macrophage의 phagocytic ability를 저해하는데, 그와 다르게 HA 분해 산물이나 저분자의 $\mathrm{HA}$ 의 경우는 상처를 치유하는 과정에서 fibrosis, deposition, collagen, inflammation을 늘어나게 하는 것으로 알려져 있으며, 류머티즘 관절염 등과 같은 염증환자에게서 고농도로 관찰되고 암세포 전이나 알레르기 반응 등에도 관여한다고 보고되었다 [29]. 그린볼 사과 적과 추출물을 이용하여 HAase의 저해활성 을 측정한 결과 Fig. $3 \mathrm{~A}$ 와 같이 phenolic compound 50-200 $\mu \mathrm{g} / \mathrm{mL}$ 농도에서 물 추출물은 28.38-35.04\%의 HAase 저해 효 과를 나타내었으며, ethanol 추출물 또한 물 추출물과 비슷한 저 해 효과를 나타내었다. Kang 등[30]의 연구에 따르면 오가피, 우슬, 갈근, 복분자도 $10 \%$ 이상의 HAase의 활성을 나타내었다
고 알려져 있다. 이러한 결과를 비교하면 오가피, 우슬, 갈근, 복분자보다 그린볼 사과 적과가 더 높은 항염증과 아토피 억제 효과를 나타낼 것이라고 판단되었다.

\section{그린볼 사과 적과 추출물의 elastase 저해 효과}

인간의 중성구 과립구 안에 있는 elastase가 피부의 탄력과 진 피 속 피부 구조를 지탱하는 일을 하는 주요한 단백질인 elastin 을 분해하는데[31], 이 효소는 이상조직에서 활성이 매우 높아 조직을 파괴하는데 주요 원인으로 작용한다[32]. 자외선과 같은 환경적 원인으로 인해 elastase의 활성이 증가하면 피부의 진피 에 있는 elastin 그물망으로 된 구조가 끊어지게 되고 감소된 피 부의 탄력섬유로 인해 피부주름이 증가한다[7,33]. 이러한 피부 주름을 해결하는 작용을 나타내는 것이 elastase 저해제이다[34]. Elastase 저해제로서 알려진 것 중 ursolic acid가 대표적이며, 

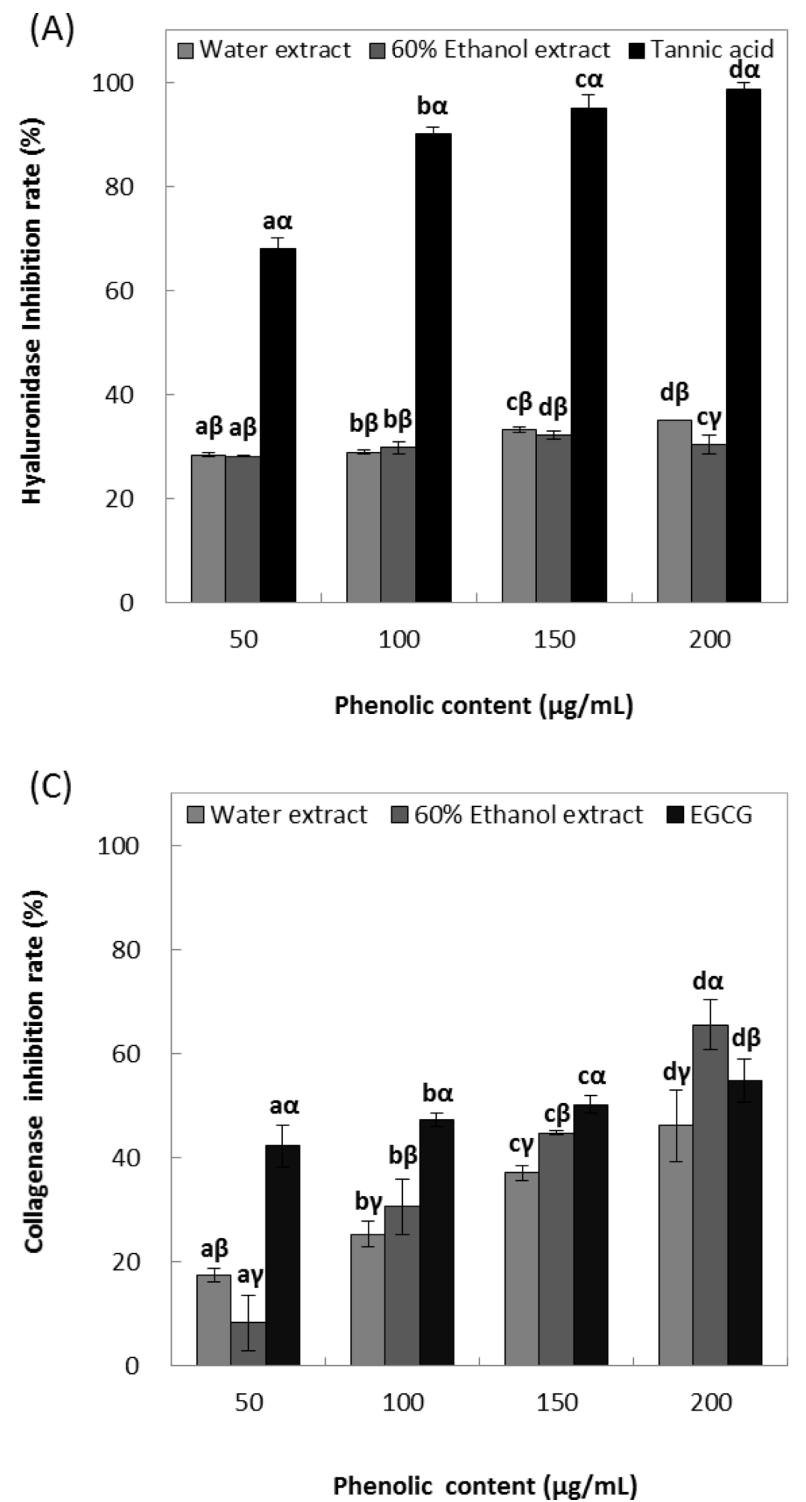

처진 피부와 주름을 완화시키는 효과가 있다고 한다[32]. Ursolic acid를 대조구로 하여 그린볼 사과 적과의 elastase에 대한 저해 활성을 측정해본 결과 Fig. $3 \mathrm{~B}$ 와 같이 phenolic compound 농 도가 $50-200 \mu \mathrm{g} / \mathrm{mL}$ 에서 물과 ethanol 추출물은 각각 9.61$47.33 \%$ 와 $15.37-40.92 \%$ 의 저해 효과를 나타냈다. 대조구인 ursolic acid는 76.40-89.99\%의 저해 효과를 나타냈다. Lee 등 [35]이 자귀나무 잎 추출물 $300 \mu \mathrm{g} / \mathrm{mL}$ 농도에서 elastase 저해 활성을 측정하였을 때 물 추출물과 ethanol 추출물 각 8 과 $7 \%$ 를 나타냈다고 보고하였다. 따라서 그린볼 사과 적과 추출물이 주름개선에 대한 기능성 소재로 활용될 가능성이 있다고 판단 되었다.

\section{그린볼 사과 적과 추출물의 collagenase 저해 효과}

Collagen, elastin, hyaluronic acid, fibronectin 등 다양한 ECM 단백질은 피부 진피층의 구성성분이다. $\mathrm{ECM}$ 단백질 전체의 $90 \%$ 를 차지하는 collagen은 피부의 형태와 강도를 유지하는 역

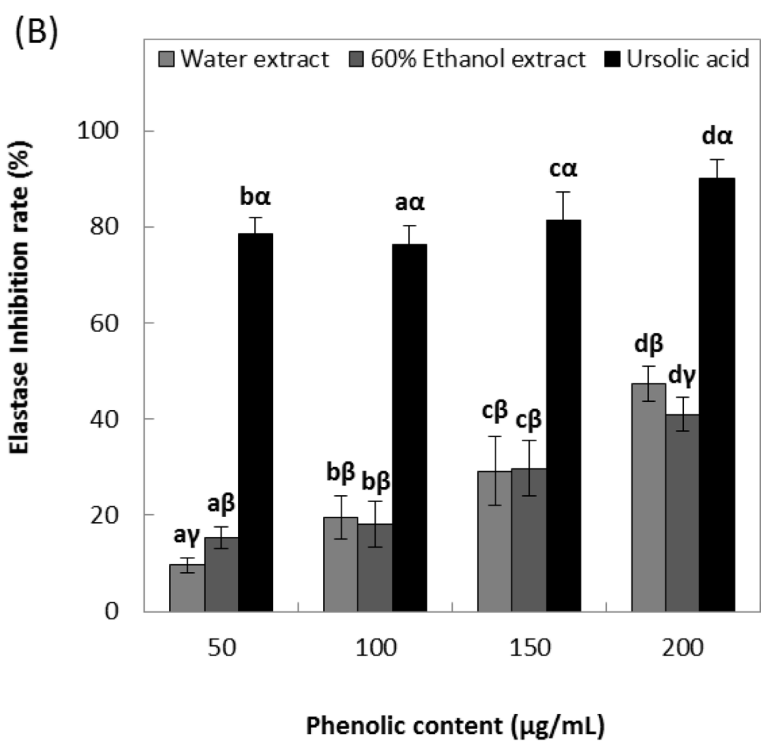

Fig. 3 inhibition activity of water, $60 \%$ ethanol extracts on hyaluronidase (A), elastase (B) and collagenase (C) from malus pumila Mill. Means with different superscript letters (a-d), $(\alpha-\gamma)$ are significantly different at $p<0.05$ by a Duncan's multiple range tests

할을 가진다. collagen은 다양한 $\mathrm{ECM}$ 단백질과 가교결합을 만 들기 때문에 collagen 분해가 일어나면서 가교결합이 끊기면서 진피층의 부피가 줄어들어 주름이 발생하며, elastin도 기능을 잃게 되어 피부의 탄력이 감소한다. Collagen은 다른 ECM 단 백질들과 비교하여 큰 부피를 가지기 때문에 collagenase에 의 한 collagen의 분해는 피부 주름 생성에 큰 영향을 미친다고 할 수 있다[24]. 그린볼 사과 적과 추출물을 이용하여 collagenase 저해 효과를 측정한 결과 Fig. $3 \mathrm{C}$ 와 같이 phenolic compound $50-200 \mu \mathrm{g} / \mathrm{mL}$ 농도의 물과 ethanol 추출물은 각각 17.49$46.19 \%$ 와 8.30-65.58\%의 저해값을 나타냈으며, positive control 로 사용한 epigallocatechin-galate (EGCG)의 42.28-54.92\%보다 낮은 값을 나타내지만, 시료가 단일 물질이 아닌 추출물임을 감 안하면 우수한 효과를 가진다고 판단되었다.

또한 그린볼 사과의 성숙과 추출물로 연구한 Lee 등[36]의 결과와 그린볼 사과 적과 추출물의 항산화 및 생리활성 효과를 비교하였을 때 주름개선 효과를 나타내는 효소인 elastase, 
collagenase 저해효과는 유사한 억제 결과를 나타내었지만, 항산 화 및 HAase 억제효과에서는 더 우수한 결과를 나타내어 그린 볼 사과 성숙과와 적과에 함유된 phenolic compounds 함량 차 이에 의한 결과라고 예상되었으며, 위 연구 결과에 따라 적과 에 함유된 성분을 활용하여 우수한 기능성의 제품에 적용 가능 할 것이라고 판단되었다.

\section{초 록}

그린볼 사과 적과의 phenolic compound를 $50-200 \mu \mathrm{g} / \mathrm{mL}$ 농도 로 처리하여 DPPH radical 소거능을 측정한 결과 $200 \mu \mathrm{g} / \mathrm{mL}$ 농도의 물과 ethanol 추출물은 94.69 과 $92.24 \%$ 의 $\mathrm{DPPH}$ radical 소거능을 나타내었다. ABTS radical 소거능은 $200 \mu \mathrm{g}$ $\mathrm{mL}$ 농도의 물과 ethanol 추출물에서 각각 100.30 과 $99.16 \%$ 의 ABTS radical 소거능을 나타내었다. PF는 $200 \mu \mathrm{g} / \mathrm{mL}$ 농도의 물과 ethanol 추출물에서 각각 $1.76,1.76 \mathrm{PF}$ 를 나타내었다. TBARs는 phenolic compound 농도가 $200 \mu \mathrm{g} / \mathrm{mL}$ 에서 물과 ethanol 추출물 각각 $101.46,99.64 \%$ 의 항산화능을 나타내었다. 염증에 관련이 있는 HAase의 저해 효과를 측정한 결과 $150 \mu \mathrm{g} /$ $\mathrm{mL}$ 농도의 물과 ethanol 추출물은 각각 $33.28,32.14 \%$ 의 저해 효과를 나타내었다. 미용식품활성을 나타내는 elastase 저해활성 을 측정해 본 결과 phenolic compound 농도가 $200 \mu \mathrm{g} / \mathrm{mL}$ 에서 물과 ethanol 추출물 각각 $47.33,40.92 \%$ 의 저해 효과를 나타 내었다. 피부의 주름과 탄력에 관련이 있는 collagenase 저해 효 과를 측정한 결과 $200 \mu \mathrm{g} / \mathrm{mL}$ 농도의 물과 ethanol 추출물은 각 각 $46.19,65.58 \%$ 를 나타내었다. 따라서 그린볼 사과 적과는 항 산화, 항염증, 주름 개선 등 다양한 생리활성을 나타내는 기능 성 소재로 개발이 가능할 것으로 판단되었다.

Keywords 그린볼 사과 적과 · 엘라스타아제 · 콜라게나제 · 항 산화 · 히알루로니다제

\section{References}

1. Shim JS, Kim SD, Kim TS, Kim KN (2005) Biological activities of flavonoid glycosides isolated from Angelica keiskei. Korean J Food Sci Techol 37: 78-83

2. Kim HC, Wu JD (2011) Review in the Effects Influencing Skin Aging and Its Prevention and Cure. Korean Journal of Aesthetics and Cosmetology 9(1): 61-169

3. Hong JK (2009) A Study on Skin Aging Caused by Free-Radical and on Efficacy of Antioxidant Vitamins. Korean Journal of Aesthetics and Cosmetology 7(2): 51-62

4. Jang JB, Park OR, Yun TE (2010) Free Radicals, Physical Performance, Aging and Antioxidants. The Korea Journal of ideal Body \& Beauty 2(1): 19-27

5. Lee EH, Cho YJ (2018) Inhibitory activities of phenolic compounds isolated from Chionanthus retusa flower on biological enzymes. Korean J Food Preserv 25(1): 117-123

6. Kwon OJ (2016) Antioxidant and tyrosinase inhibitory activities of immature fruits of Malus pumila cv. Fuji. Korean J Food Preserv 23: $585-590$

7. Vinson JA, Su X, Zubic L, Bose P (2001) Phenol antioxidant quantity and quality in foods: fruits. J Agric Food Chem 49: 5315-5321
8. Lee EH, Kim YJ, Kwon SI, Kim JH, Kang IK, Kim BO, Cho YJ (2018) Functional properties of newly bred Green ball apple (Malus pumila Mill.). Korean J Food Preserv 25(7): 837-845

9. Folin O, Denis W (1912) On phosphotungastic phosphomolybdic compounds as color reagents. J Biol Chem 12: 239-249

10. Blois MS (1958) Antioxidant determinations by the use of a stable free radical. Nature 181: 1199-1200

11. Fellegrini N, Ke R, Yang M, Rice-Evans C (1999) Screening of dietary carotenoids and carotenoid-rich fruit extracts for antioxidant activities applying 2,2'-azinobis (3-ethylenebenzothiazoline-6-sulfonic acid radical cation decolorization assay. Method Enzymol 299: 379-389

12. Andarwulan N, Shetty K (1999) Phenolic content in differ-transformed roots of anise (Pimpinella ansisum L.). J Agric Food Chem 47: 17791780

13. Buege JA, Aust SD (1978) Microsomal lipid peroxidation. Methods Enzymol 52: 302-310

14. Dorfman A, Ott ML (1948) A turbidimetric method for the assay of hyaluronidase. J Biol Chem 172: 367-375

15. Kraunsoe JA, Claridge TD, Lowe G (1996) Inhibition of human leukocyte and porcine pancreatic elastase by homologues of bovine pancreatic trypsin inhibitor. Biochemistry 35: 9090-9096

16. Wunsch E, Heidrich HG (1963) Zur quantitativen bestim-mung der kollagenase. Hoppe-Seyler's Z Physiol Chem 333: 149-151

17. Ahn SI (2005) Antioxidative and physiological activities of some phenolic compounds. Dissertation, National University of Hankyong

18. Kang SA, Han JA, Jang KH, Choue RW (2004) DPPH Radical Scavenger Activity and Antioxidant Effects of Cham-Dang-Gui (Angelica gigas). J Korean Soc Food Sci Nutr 33(7): 1112-1118

19. Kim YH, Lee YJ, Park SO, Lee SJ, Lee OH (2013) Antioxidant Compounds and Antioxidant Activities of Fermented Black Rice and Its Fractions. Korean J Food Sci Technol 45: 262-266

20. Lee EH, Kim BO, Cho YJ (2017) Inhibitory activities on biological enzymes of extracts from Oplismenus undulatifolius. J Appl Biol Chem 60: $101-108$

21. Sung NE (1989) The Effect of BHA and BHT on Mixed Function Oxygenase of Liver Tissue. Ewha medical journal 12: 7-11

22. Kim HS, Kang YH (2010) Antioxidant Activity of Ethanol Extracts of Non-Edible Parts (stalk, stem leaf, seed) from Oriental Melon. Korean J Plant Res 23(5): 451-457

23. Chae JW (2012) Antioxidative Activity of Extracts from Sambucus williamsii var. coreana. Korean J Plant Res 25(4): 363-371

24. Lim SB (2018) Anti-oxidant and Enzyme Inhibition Activities of Freezedried Powder from Cedrela sinensis fruit. J Korean Soc Food Sci Nutr 47(11): 1085-1092

25. Lim SB, Kim MW, Park KI, Lee EH, Kim YJ, Cho EB, Kim BO, Cho YJ (2018) Biological activity of wild Ligularia fischeri leaf extracts in the development of functional food materials. Korean J Food Preserv 25(3): 359-365

26. Joo SY (2013) Antioxidant activities of medicinal plant extracts. J Korean Soc Food Sci Nutr 42: 512-519

27. Kim JH, Lee SY, Park JM, Park JH, Kwon OJ, Lee JY (2014) Antioxidant activity and inhibition activity against $\alpha$-amylase and $\alpha$ glucosidase of Juniperus rigida Sieb extracts. Korean J Food Preserv 21: 396-403

28. Kwon JY, Cheong SI (2005) Characterization of Hyaluronic Acid Membrane Containing Lactic Acid. Membrane Journal 15: 8-14

29. Lee EH, Hong SH, and Cho YJ (2017) Biological Activities of Extracts from Okkwang (Castanea crenata) Chestnut Bur. J Korean Soc Food Sci Nutr 46: 572-580

30. Kang CH, Kwak DY, So JS (2013) Inhibition of Nitric Oxide Production and Hyaluronidase Activities from the Combined Extracts of Platycodon grandiflorum, Astragalus membranaceus, and Schisandra chinensis. J Korean Soc Food Sci Nutr 42(6): 844-850

31. Lee JY, Yu MR, An BJ (2010) Comparison of biological activity between Nelumbo nucifera G. extracts and cosmetics adding Nelumbo 
nucifera G. J Life Sci 20: 1241-1248

32. Tsuji N, Moriwaki S, Suzuki Y, Takema Y, Imokawa G (2001) The role of elastases secreted by fibroblasts in wrinkle formation: implication through selective inhibition of elastase activity. Phytochem Photobiol 74: 283-290

33. Tsukahara K, Nakagawa H, Moriwaki S, Takema Y, Fujinura T, Imokawa $\mathrm{G}$ (2006) Inhibition of ultraviolet-B-induced wrinkle formation by an elastase-inhibiting herbal extract: implication for the mechanism underlying elastase-associated wrinkles. Int J Dermatol 45: 460-468

34. Dewitt DL, Rollins TE, Day JS, Gauger JA, Smith WL (1981)
Orientation of the active site, and antigenic determinants of prostaglandin endoperoxide of synthase in the endoplasmic reticulum. J Biol Chem 256: $10375-10382$

35. Lee YS, Kim BO, Kim NW (2014) Anti-wrinkle and antioxidant activity of the extract of Albizzia julibrissin leaves. J Invest Cosmetol 10: 317326

36. Lee EH, Kim YJ, Kwon SI, Kim JH, Kang IK, Kim BO, Cho YJ (2018) Functional properties of newly bred Green ball apple (Malus pumila Mill.) Korean J Food Preserv 25: 837-845 